\title{
PROGRAMME OF ACTIVE EDUCATION IN THE PSYCHO-SOCIAL INTEGRATION OF PARAPLEGICS
}

\author{
By A. Pachalski, M.D., M.B., and M. M. Pachalska, Ph.D., C.C.C. \\ The Crakov Institute of Rehabilitation, Crakov, Poland, Al Planu 6-letniego 62 a.
}

Summary. This is a programme involving active education in which not only those with paraplegia but also their families participate. The purpose is to break down the psycho-social isolation barrier of the patient and, thereby, resulting in minimal dependence upon his surroundings. Also, presented are the results of tests made of the persons participating in this project. These tests indicate the efficacy of the method in obtaining the desired results.

Key words: Rehabilitation of paraplegics; Psycho-social integration; Programme of active education.

\section{Introduction}

IT HAS been observed, during many years of clinical practice, that even the best rehabilitation centre is not able to solve the many problems which face paraplegics, causing a feeling of isolation and alienation, thereby leading to frustration and/or aggression. (Forner et al., I976; Jenik et al., I982; Johnson et al., I972; Pachalski et al., I982). He ceases to function as an individual and becomes more and more dependent on society (Sutton et al., 1982).

On the basis of statements by psychologists and sociologists that the family provides the best possibilities for the socialisation of its members, we have developed a programme which gives members of the patients' families the knowledge necessary for them to assist in the process of rehabilitation.

This programme focusses on five areas of activity, i.e. tasks, recreation, direct goal of movement, creative motion expression and problems. In all these areas there is interaction between therapist, family and paraplegic. In order that the family may participate effectively they take part with the patient in a period of training, based on a plan which emphasizes the needs of the paraplegic. The role of the therapist, as shown in Table I, is to develop such a plan, to introduce it to a patient and his family and to monitor its fulfilment. The psychological and social aims are stated in Table II.

The programme embraces three scientific fields, i.e. medical, kinesitherapeutic and psychosocial.

\section{Material}

The programme was introduced as a method of treatment in the Cracov Rehabilitation Centre. In all 38 paraplegics, that is I 8 male and 20 female and their families, were treated under this regime. These patients constitute experimental Group A. 
TABLE I

Functional structure of the Active Education Programme

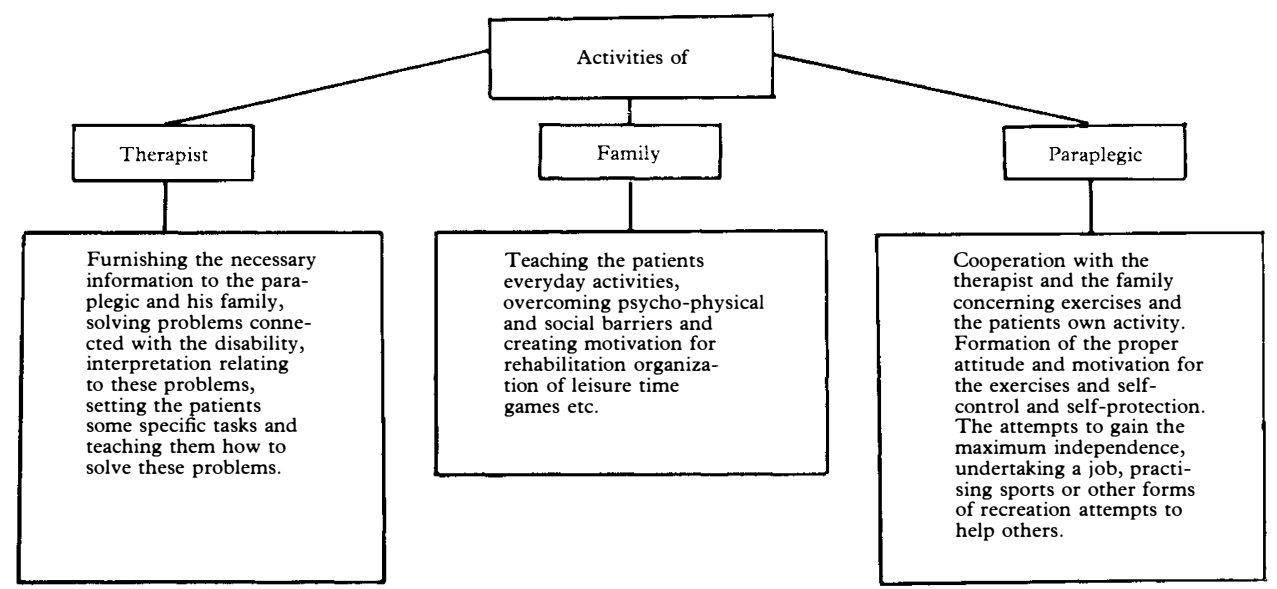

TABLE II

The aim of the Active Education Programme

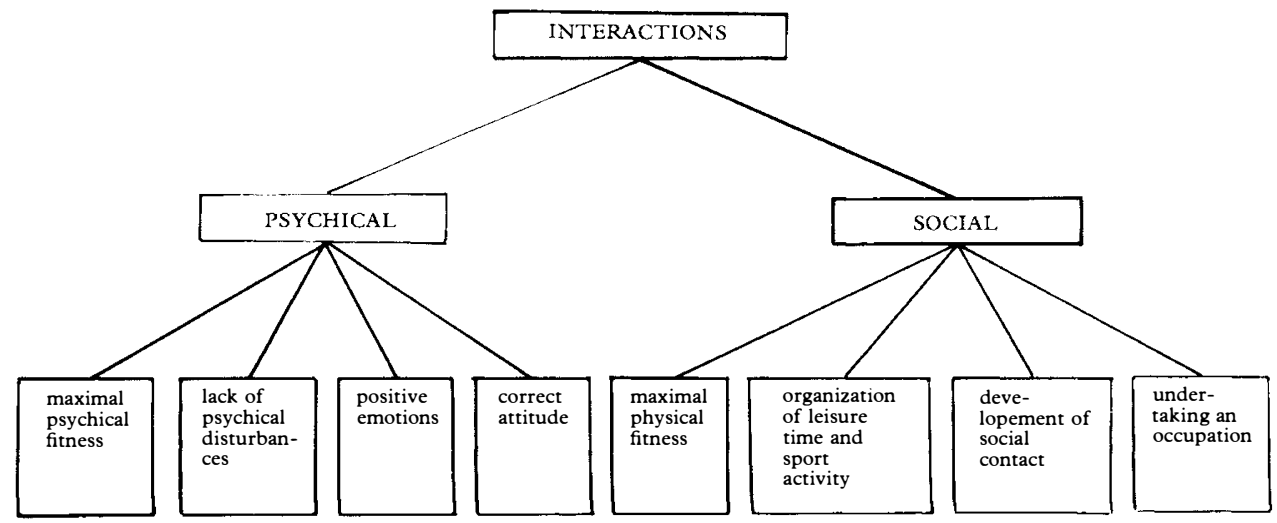

In order to determine the effectiveness of the programme, we conducted additional examinations of 37 paraplegics, that is 19 male and I 8 female, who were also treated in our Centre and designated Group B.

The AE (Active Education) programme was not used in this group.

The examinations were conducted twice: initially, and after a three month period of treatment.

\section{Method}

The survey was carried out by a neuropsychologist and a social worker. The survey included a semi-structured interview schedule and the following scales: I. Self-evaluation by the paraplegic of his adaptation to his environment; 2. Evaluation of psychical integration; 3 . Social independence; and 
4. Frustration and Aggression Test. A computerised analyses of these results was obtained.

\section{Results}

The programme introduced, i.e. the active education of paraplegics and their families, had a positive effect in the therapy of the paraplegics which is shown by the data obtained during the research.

Self-evaluation by the paraplegic of his adaptation to his environment is presented in Table III.

In this study (before treatment), the majority of the patients in both groups believed themselves to be unadapted socially. The unadapted consisted of 12 males and I 4 females in Group A and 12 males and 13 females in Group B. Only a few persons felt that they were well adapted.

These results changed considerably after rehabilitation in Group A. During the second control examination most of the patients evaluated the effects of their treatment to society as good or as very good.

In group B (after treatment), only a few persons felt that their adaptation was good or very good.

The above data indicates that the paraplegics, after completing the $\mathrm{AB}$ programme, believed themselves to be better adapted to society.

Since the data obtained showed no significant difference between males and females in both groups $\mathrm{A}$ and $\mathrm{B}$, further analysis will be carried out without regard to sex.

An analysis of the 'Evaluation scale of the psychical integration of the paraplegics', in the first examination of group A and B, shows a preponderance of negative results in psychical integration. An analysis of the data indicates, in all spheres examined, a high percentage of disintegration, i.e.

TABLE III

Self-evaluation of adaptation to environment

\begin{tabular}{|c|c|c|c|c|c|c|c|}
\hline \multirow[b]{2}{*}{ Group } & \multirow{2}{*}{$\begin{array}{l}\text { Rese- } \\
\text { arch } \\
\text { no: }\end{array}$} & \multirow[b]{2}{*}{ Sex } & \multirow[b]{2}{*}{ no } & \multicolumn{4}{|c|}{ Social Adaptation } \\
\hline & & & & very good & good & $\begin{array}{l}\text { satisfac- } \\
\text { tory }\end{array}$ & $\begin{array}{l}\text { unsatis- } \\
\text { factory }\end{array}$ \\
\hline \multirow{4}{*}{ A } & \multirow[b]{2}{*}{ I } & $\delta$ & 18 & 1 & 1 & 4 & 12 \\
\hline & & ? & 20 & 0 & 1 & 5 & 14 \\
\hline & \multirow{2}{*}{ II } & $\alpha$ & 18 & 7 & 8 & 2 & 1 \\
\hline & & 0 & 20 & 6 & 9 & 5 & 0 \\
\hline \multirow{4}{*}{ B } & \multirow{2}{*}{ I } & $\sigma$ & 19 & 0 & 2 & 5 & 12 \\
\hline & & Q & 18 & 0 & 1 & 4 & 13 \\
\hline & \multirow{2}{*}{ II } & $\delta$ & 19 & 2 & 3 & 7 & 7 \\
\hline & & 0 & 18 & 1 & 2 & 6 & 9 \\
\hline
\end{tabular}


90 per cent in group A and 95 per cent in group B had apprehension and fears. Also, 85 per cent in group A and $8 \mathrm{I}$ per cent in group B had a negative attitude toward their abilities and toward their entire future. A large number (80 per cent) in group A and 75 per cent in group B had a feeling of guilt as well as a negative opinion of their past. A somewhat smaller percentage ( 70 per cent) in group A and 68 per cent in group B did not see any aim in life. This fact is evidence of the disintegration of the persons examined.

An examination after treatment, showed a change in the situation. More patients from group A saw before them a future, found a goal in life and evaluated positively their worth; feelings of guilt and threat decreased as did fear. All this may be interpreted as a release of the patients from dependence upon their environment.

The psychical integration of the paraplegics in group $A$, stated in percentages, indicates that in all seven spheres examined there arose statistical differences, evident on the level $\propto=0.0$ I between examination I and II.

In group $\mathrm{B}$, there were no significant differences in this area after treatment.

The data obtained in the 'Frustration and Aggression Test' also showed in group A large differences between the first and the second examination. The control examination, after treatment, shows a clear decrease in aggression, an average of 50 per cent. In all 16 variants of the examination there was a considerable decrease in aggression. In group B the frustration/ aggression level was similar before and after treatment.

From this we may conclude that the AE Programme also influences the decrease in aggression and frustration of paraplegics.

The AE Programme also decreased the patients' dependence (Fig. I).

In the first examination in group A 60 per cent of the patients did not make use of any means of transportation.

The second examination showed that only is per cent of the patients still did not use any means of transportation nor go for walks. A qualitative analysis of this fact indicated that these were patients in whose homes, for various reasons, we could not eliminate architectural barriers.

After the introduction of the AE programme into the model of rehabilitation the number of non-working patients in group A fell considerably from 60 per cent to 30 per cent; also the percentage of working patients increased.

The number of patients making use of 'bus, tram and train, increased from i 5 to 55 per cent.

The AE programme has also helped patients to organise their own activities and free time. In the second examination the majority of the patients in group A take part in sports and attend the cinema, theatre and philharmonic concerts and also read books. Most of those examined attend rehabilitation camps.

In group B no significant statistical differences were noted before and after treatment in any of the parameters discussed above.

A qualitative analysis of this fact shows that the AE programme helps in the everyday life, work and play of paraplegics, through an educational programme invading them and their families. 


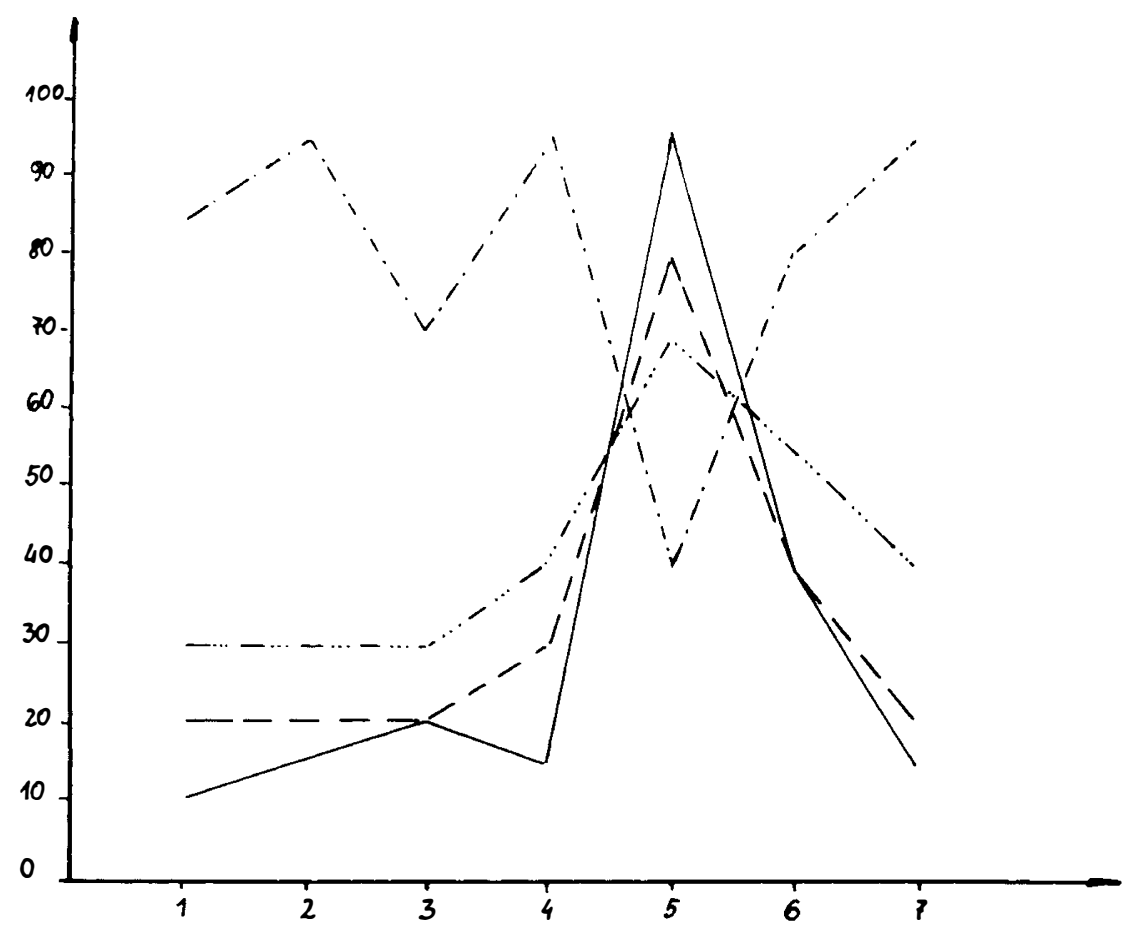

FIG. I

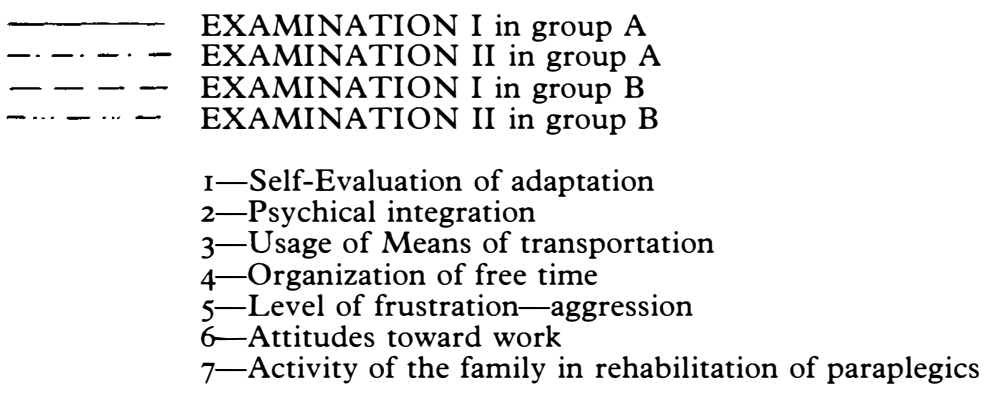

\section{RÉSUMÉ}

Au Centre Cracovien de la Rehabilitation on a elabore le programme de l'education active des paraplegiques et de leurs familles/nomme AE-Programme/dont le but est la plus grande integration psychosocial de ce group de malades.

Global on a fait 75 examens des paraplegiques. 37 paraplegiques c'est la grouppe control. Les 38 examens des paraplegiques ces examens ont prouve une grande utilite pratique d' AE-Programme quant a l'education convenable de la famille, changement du rapport au malade creation de l'ambiance therapeutique et augmentation de son activite au cours de la rehabilitation des paraple-giques. L'AE-Programme contribue a l'integration autant psychique/il fait eliminer la reaction a l'infirmite et les autres troubles psychiques/que sociale/il fait augmenter l'independance des malades, leur adaptation au milieu, leur retour au travail/.

Les resultats obtenus parlent en faveur de l'introduction plus vaste d'AE-Programme au Modele de rehabilitation des malades atteints de la paraplegie. 


\section{ZUSAMMENFASSUNG}

In dem Krakauer Rehabilitationszentrum Wurde das Programm der aktiven Erziehung/AEProgramm/fur Paraplegiker und ihre Familien ausgearbeitet. Das Programm hatte zum Ziel die maximale Psychosoziologische Integration der Kraken.

Global es sind 75 Paraplegiker. 37 Paraplegiker ist die control group.

Es sind 38 Paraplegiker untersucht wordem, und diese untersuchungen haben eine grosse Verwendbarkeit des AE-Programm im bezug auf die angemessene Erziehung der Famille vor allem auf die Veranderung ihres Verhaltens dem Kraken gegenuber und die Herausbildung der therapautischen Atmosphere und die Erhohung iher Aktivitat im Rehabilitationsprozess der Paraplegiker gezeist. Das AE-Programm fugt sowohl psychische Integration/Eliminierung der negativen Reaktionen auf die Juralitat und anderer psychischen Storungen/also auch die soziale Integration/Erhohung der Selbststandigkeit der Kraken ihre Anpassung an das Milieau ihre Ruckkehr zur Arbeit/herbei.

Die erworbehen Ergebnisse sprechen fur die breitere Einfuhrung des AE-Programm ins Rehabilitationsmodel der an Paraplegie leidende Kraken.

\section{REFERENCES}

Forner, J. V., Miro, R., Manteiga, A, Suares, S. \& Serra, M. (i976). Social and working conditions of our paraplegics. Paraplegia, 14, 74-78.

JeNIK, F., KUHN, W. \& ZACH, G. A. (I982). Social and vocational reintergration of paraplegic and tetraplegic patients in Switzerland. Paraplegia, 20, 65-70.

Johnson, G. S., Johnson, R. H. \& BowIE, G. (1972). Problems of social integration for paraplegics in Scotland. Paraplegia, 10, 126-133.

Pą̧Chalski, A., KuZak Pa̧ChalsKa, M. \& MȨKarski, T. (I982). The relation between social achievement and the degree of improvement of paraplegic patients in the region of Cracov. Paraplegia, 20, 296-298.

Sutton, R. A., Bentley, M. Castree, B., Mattinson, R., Pattinson, J. \& Smith, R. (i 982 ). Review of the social situation of paraplegic and tetraplegic patients rehabilitated in the Hexham regional spinal injury unit in the north of England over the past four years. Paraplegia, 20, 7 I-79. 